\title{
A study of water-soluble inorganic ions in size-segregated aerosols in atmospheric pollution episode
}

\author{
M. A. Leiva G. • R. Toro • R. G. E. Morales • \\ M. A. Ríos • M. R. González
}

Received: 14 July 2012/Revised: 12 February 2013/Accepted: 23 February 2013/Published online: 20 March 2013

(C) Islamic Azad University (IAU) 2013

\begin{abstract}
Particulate matter, the main pollutant in the atmospheric environment of the Santiago city in winter, was analyzed by means of the major water-soluble ionic species obtained under critical episodes of pollution in 2003. The particulate matter samples were collected using the Micro-Orifice uniform deposit impactors, with eight impactor stages connected in series, and the ionic species in particulate matter samples at each stage was analyzed by ion chromatography. While sulfate ion and nitrate ion showed bi-modal distributions, peaking in the fine and coarse mode, ammonium ion displayed a bi-modal size distribution, peaking in the fine and ultra fine mode. The equivalent concentration ratio of ammonium to sulfate was $2.03 \pm 0.09$, indicating the complete neutralization of sulfuric acid by ammonia. The excess ammonium ion was associated to nitrate ion. The study of the size distribution of water-soluble inorganic ions in particulate matter supports the notion that secondary aerosols play a significant role in the urban atmosphere.
\end{abstract}

Keywords Ammonium · Nitrate · Particle-size distribution $\cdot$ Secondary particles $\cdot$ Sulfate

\section{Introduction}

Atmospheric aerosols are either emitted directly into the atmosphere (primary aerosols) or formed in the atmosphere

M. A. Leiva G. $(\bowtie) \cdot$ R. Toro · R. G. E. Morales

M. A. Ríos · M. R. González

Centro de Ciencias Ambientales and Departamento

de Química, Facultad de Ciencias, Universidad de Chile,

Casilla 653, Santiago, Chile

e-mail: manleiva@me.com by gas-to-particle conversion processes (secondary aerosols) (Salve et al. 2007; Verma et al. 2010; Xiu et al. 2004). Increases in the concentration of fine particles generally occur during the autumn and winter period. Therefore, nitrate $\left(\mathrm{NO}_{3}{ }^{-}\right)$, ammonium $\left(\mathrm{NH}_{4}{ }^{+}\right)$, and sulfate $\left(\mathrm{SO}_{4}{ }^{2-}\right)$ are significant constituents of the inorganic particulate matter (PM), which is formed primarily by the conversion of ammonia $\left(\mathrm{NH}_{3}\right)$ to $\mathrm{NH}_{4}{ }^{+}$(Behera and Sharma 2010; Krupa 2003). $\mathrm{NH}_{3}$ is one of the most significant alkaline gases in the atmosphere and plays a major role in the neutralization of acidic atmospheric gases. The major sources of atmospheric $\mathrm{NH}_{3}$ are agriculture, industry, wetlands, landfills, household products, biomass burning, motor vehicles, and wild animals (Krupa 2003).

In the atmosphere, for a system containing sulfuric acid $\left(\mathrm{H}_{2} \mathrm{SO}_{4}\right)$, nitric acid $\left(\mathrm{HNO}_{3}\right)$, and $\mathrm{NH}_{3}$, thermodynamic constraints favor the formation of ammonium sulfate salts prior to equilibrium formation of ammonium nitrate (Du et al. 2010). In other words, if there is insufficient ammonia to fully neutralize the sulfate (a 2:1 molar ratio is required since two ammonia molecules pair with one sulfate to form fully neutralized $\left(\left(\mathrm{NH}_{4}\right)_{2} \mathrm{SO}_{4}\right)$, nitrate is not expected to coexist with the sulfate in submicron particles. If excess ammonia is available, ammonium nitrate $\left(\mathrm{NH}_{4} \mathrm{NO}_{3}\right)$ can be formed (Baek et al. 2004). $\mathrm{NH}_{4} \mathrm{NO}_{3}$ is very sensitive to low temperature and high humidity; on the other hand, $\mathrm{HCl}$, as well as $\mathrm{H}_{2} \mathrm{SO}_{4}$ and $\mathrm{HNO}_{3}$, reacts quickly with $\mathrm{NH}_{3}$ in aqueous phase to form ammonium chloride $\left(\mathrm{NH}_{4} \mathrm{Cl}\right)$ salt, which is thermodynamically unstable under normal atmospheric conditions (Baek et al. 2004).

The chemical relationships that allow a secondary aerosol formation are all influenced by temperature and relative humidity as well as the availability of the chemicals themselves. Sulfuric acid will readily condense into particle form, independent of the availability of ammonia or 
nitric acid. This gas-to-particle conversion process is favored at high relative humidity (Krupa 2003). For ammonium nitrate, sufficient quantities of ammonia are required to bond with nitric acid. However, if sulfuric acid is present in aqueous media, ammonia will react first with the sulfuric acid than nitric acid. But, if excess of ammonia is available at high relative humidity and low temperatures, the formation of ammonium nitrate will be favorable under similar atmospheric conditions.

The particle-size distributions and chemical composition of the major water-soluble inorganic ions present in aerosols (urban, rural, and remote sites around the world), make up a research subject because they permit determining the relative importance of the formation of particulate pollutants in the atmosphere (Morales and Leiva 2006; Tsai et al. 2005; Xiu et al. 2004; Zhao et al. 2011). In urban areas, in general, the studies showed that $\mathrm{NH}_{4}{ }^{+}$was found to be predominantly in the fine particle mode and $\mathrm{Cl}^{-}$and $\mathrm{Ca}^{2+}$ were more abundant in the coarse fraction (Tsai et al. 2005; Xiu et al. 2004). In the case of $\mathrm{K}^{+}$it was more abundant in the fine mode (Chen et al. 2005; Tsai et al. 2005; Xiu et al. 2004). However, $\mathrm{SO}_{4}{ }^{2-}$ and $\mathrm{NO}_{3}{ }^{-}$form fine and coarse modes by the reaction of $\mathrm{H}_{2} \mathrm{SO}_{4}(\mathrm{~g})$ and $\mathrm{HNO}_{3}$ (g) with $\mathrm{NH}_{3}$ (g) (Parmar et al. 2001). In some cases, a bi-modal or tri-modal distribution is needed to describe the size distribution of inorganic ions (Milford and Davidson 1987). Recently, major water-soluble inorganic ions in urban areas have shown a significant fraction of fine and ultrafine sulfate and nitrate (Lin et al. 2007). The increase of the diesel vehicular fleet along with the type of fuels used in combustion process could be one of the reasons for the observed increase in ultrafine concentrations of these species (Maricq 2007; Morawska et al. 2008). This growth is important from a health perspective because the ultrafine particles can have a much stronger physiological effect than coarse particles (Donaldson et al. 1998; Wichmann et al. 2000).

Santiago city $\left(33.5^{\circ} \mathrm{S}, 70.6^{\circ} \mathrm{W}\right)$ exhibits high concentration of particulate matter (PM) due to the anthropogenic activity of the city's nearly six million inhabitants (Fig. 1) (Leiva et al. 2012; Morales and Leiva 2006; Morata et al. 2008). Due to the high levels of urban $\mathrm{PM}$, in 1996 the city of Santiago was declared $\mathrm{PM}_{10}$, i.e., particulate matter with an aerodynamic diameter of 10 micrometers or less, and carbon monoxide (CO) saturated ambient, by the Environmental Minister (formerly the National Commission of Environment). High concentrations of particles are predominant in the Pudahuel area, located in the western part of the city. The hourly values for total concentration of particulate matter in Santiago is near to $300 \mu \mathrm{g} \mathrm{m}^{-3}$ with peaks near $500 \mu \mathrm{g} \mathrm{m}^{-3}$ in 2003 . It has been shown that fine particulate matter up to 2.5 micrometers in size $\left(\mathrm{PM}_{2.5}\right)$ comprises more than $50 \%$ of the total $\mathrm{PM}_{10}$ concentration (SINCA 2011). These results are a strong signal that Pudahuel area is one of the zones mostly affected by the atmospheric pollution in Santiago city, Chile.

In the past two decades the atmospheric pollution studies in the city of Santiago have been focused on quantification of heavy metal content and emission source characterization. However, a preliminary study of urban atmospheric ammonia, with passive tubes, has been determinant to analyze the major water-soluble inorganic ions and their size distributions in these urban atmospheric aerosols (CONAMA 1999; Toro 2010).

Therefore, the present study has been focused on the major water-soluble inorganic ions in atmospheric aerosol in the Santiago metropolitan area during an important campaign developed in a winter pollution episode in 2003, a particular year of high pollution level observed during the past decade (Toro 2010). The size-resolved characteristics of particle masses and chemical compositions were investigated to explore possible pathways for the formation of secondary compounds.

\section{Materials and methods}

\section{Study area and measurements sites}

The city of Santiago $\left(33.5^{\circ} \mathrm{S}, 70.6^{\circ} \mathrm{W}\right)$ is located in a valley between two rivers, the Maipo and Mapocho, in the central zone of Chile. The city covers a surface area of approximately $1,400 \mathrm{~km}^{2}$ and lies $500 \mathrm{~m}$ above sea level. It is bounded by the high Andes (4,500 $\mathrm{m}$ altitude on average) to the east, a lower parallel mountain range to the west (1,500 $\mathrm{m}$ altitude on average), and two east-to-west mountain chains to the north and south of the basin (Fig. 1) (Morales and Leiva 2006; Morata et al. 2008). The Mediterranean-like weather in Santiago is characterized by the quasi-permanent influence of the subtropical Pacific High.

Air pollutants and meteorological condition measurements

Eight monitoring stations distributed throughout the city measure the concentrations of pollutant gases and atmospheric aerosols $\left(\mathrm{SO}_{2}, \mathrm{O}_{3}, \mathrm{CO}\right.$ and $\left.\mathrm{PM}_{10}\right)$ and determine the current meteorological data (temperature, relative humidity, wind velocity, and wind direction) (SINCA 2011). All of these stations support the MACAM-2 network and the Air Quality Monitoring Program in Santiago Metropolitan Area (Fig. 1 and Table 1). However, only four stations determine $\mathrm{PM}_{2.5}$ : Las Condes, La Florida, Parque O'Higgins, and Pudahuel (Fig. 1). However, the Pudahuel area is located near the international airport and 


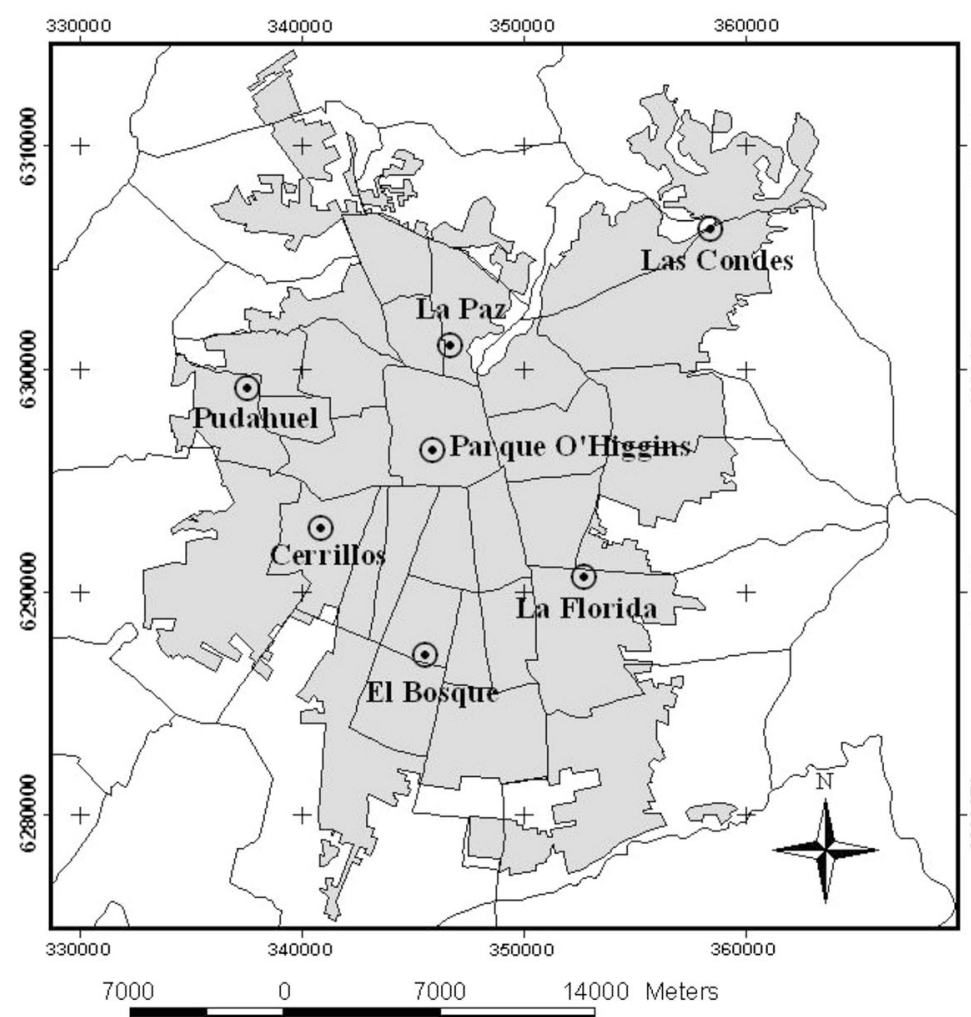

$\odot$ MACAM-2 Network

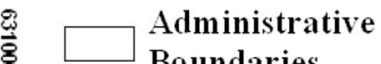

Boundaries

Urban Zone

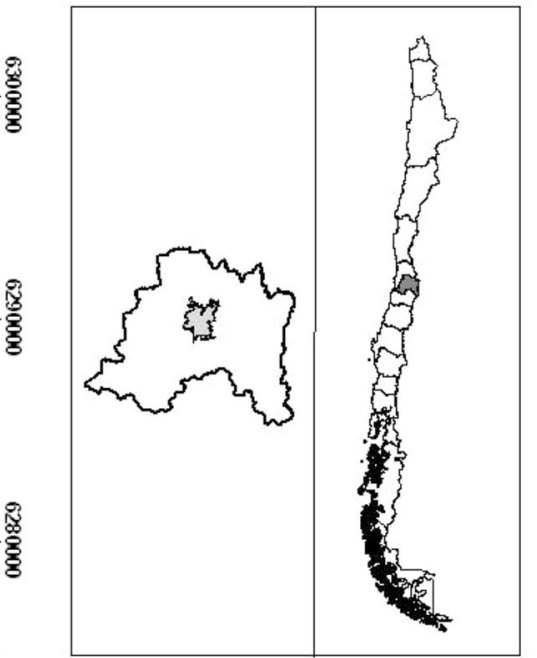

Fig. 1 Monitoring air quality network of Santiago, Chile and locations of the stations. The gray area is the urban region, and the black lines represent the administrative boundary

is the main rural place of the metropolitan region, which is characterized by agricultural, wetlands, swamps, and quiet waters area. Therefore, we have focused our studies on this particular urban zone.
$\mathrm{PM}_{10}$ and $\mathrm{PM}_{2.5}$ concentrations were determined by means of Tapered-Element Oscillating Microbalance (TEOM) equipment (Thermos Co., Illinois, USA), which provides data every $5 \mathrm{~min}$ at $50{ }^{\circ} \mathrm{C}$. The data obtained

Table 1 Sampling period, meteorological conditions and PM10, PM2.5 concentration

\begin{tabular}{|c|c|c|c|c|c|c|}
\hline \multirow[t]{2}{*}{ Meteorological conditions } & \multicolumn{6}{|l|}{ Sampling period } \\
\hline & $\begin{array}{l}\text { M1 } \\
\text { M1 + M2 }\end{array}$ & M2 & $\begin{array}{l}\text { M3 } \\
\text { M3 + M4 }\end{array}$ & M4 & $\begin{array}{l}\text { M5 } \\
\text { M5 + M6 }\end{array}$ & M6 \\
\hline \multirow[t]{2}{*}{ Sampling period (mm.dd (hh:mm)) } & May 15 (18:00) & May 19 (17:00) & May 29 (11:00) & Jun 02 (13:00) & Jun 12 (16:00) & Jun $16(12: 00)$ \\
\hline & May 19 (16:00) & May $22(16: 00)$ & Jun $02(12: 00)$ & Jun $06(16: 00)$ & Jun $16(12: 00)$ & Jun $19(15: 00)$ \\
\hline Sampling volume $\left(\mathrm{m}^{-3}\right)$ & 136.372 & 57.355 & 128.842 & 98.553 & 134.323 & 104.420 \\
\hline \multirow[t]{2}{*}{ Temperature $\left({ }^{\circ} \mathrm{C}\right)$} & $9.6(4.3)$ & $11.7(2.3)$ & $11.7(3.5)$ & $10.8(3.6)$ & $11.2(3.3)$ & $11.8(3.6)$ \\
\hline & $10.5(3.7)$ & & $11.3(3.6)$ & & $11.5(3.4)$ & \\
\hline \multirow[t]{2}{*}{ Relative humidity (\%) } & $63(16)$ & $78(13)$ & $82(16)$ & $83(13)$ & $83(12)$ & 79 (16) \\
\hline & $70(17)$ & & $82(15)$ & & $81(14)$ & \\
\hline \multirow[t]{2}{*}{ Wind direction $\left({ }^{\circ}\right)$} & $210(93)$ & $166(111)$ & $205(92)$ & $199(91)$ & $204(105)$ & $204(101)$ \\
\hline & $191(103)$ & & $202(92)$ & & $204(103)$ & \\
\hline \multirow[t]{2}{*}{ Wind speed $\left(\mathrm{m} \mathrm{s}^{-1}\right)$} & $0.94(0.76)$ & $1.57(1.02)$ & $1.17(0.91)$ & $1.11(0.84)$ & $1.26(1.01)$ & $0.91(0.51)$ \\
\hline & $1.21(0.93)$ & & $1.14(0.88)$ & & $1.11(0.84)$ & \\
\hline \multirow[t]{2}{*}{ PM10 $\left(\mu \mathrm{g} \mathrm{m}^{-3}\right)$} & $173(85)$ & $66(78)$ & $121(90)$ & $98(52)$ & $59(40)$ & $119(63)$ \\
\hline & $127(98)$ & & $111(77)$ & & $86(59)$ & \\
\hline \multirow[t]{2}{*}{$\mathrm{PM} 2.5\left(\mu \mathrm{g} \mathrm{m}^{-3}\right)$} & $91(50)$ & $35(43)$ & $81(60)$ & $59(27)$ & $28(21)$ & $58(30)$ \\
\hline & $67(55)$ & & $72(50)$ & & $42(29)$ & \\
\hline
\end{tabular}


were previously validated to fix vacancies, duplicated entries, and gaps.

\section{Particle-size distribution sampling}

Particle-size distribution sampling was performed at the Pudahuel station between 15 May and 19 June 2003, and a set of six particle-size distribution samples were obtained on the following dates: May 15-19, May 19-22, May 29June 2, June 2-5, June 12-16, and June 16-19. Table 1 and Fig. 3 detail the meteorological conditions observed during the sampling periods.

A Multi-Orifice Uniform Deposit Impactor (MOUDI) model 110 (Applied Physics Inc. Co., USA) was used to collect size-segregated aerosol samples (Marple et al. 1991). The eight stages of the MOUDI cascade impactor had $\mathrm{D}_{50}$ size cuts at $18,3.2,1.8,1.0,0.56,0.32,0.175$, and $0.093 \mu \mathrm{m}$ equivalent aerodynamic diameters. A Teflon after-filter collected all particles $<0.093 \mu \mathrm{m}$ in size. A three-size group was defined for the present study: coarse $\left(\mathrm{PM}_{18-3.2}, \mathrm{PM}_{3.2-1.8} ; 1.8 \mu \mathrm{m}<\mathrm{Dp}<18 \mu \mathrm{m}\right)$, fine $\left(\mathrm{PM}_{1.8-1.0}\right.$, $\mathrm{PM}_{1.0-0.56}, \quad \mathrm{PM}_{0.56-0.32}, \quad \mathrm{PM}_{0.32-0.175}, \quad \mathrm{PM}_{0.175-0.093} ; 0.1$ $\mu \mathrm{m}<\mathrm{Dp}<1.8 \mu \mathrm{m})$, and nuclei $(\mathrm{Dp}<0.1 \mu \mathrm{m})$ particles. The flow rate for the MOUDI was $30 \mathrm{Lmin}^{-1}$. Particulates were collected using $47 \mathrm{~mm}$ Teflon filters with $0.20 \mu \mathrm{m}$ pore size (Advantec MFS Inc., CA, USA). Each filter was weighed before and after sample collection to determine the net mass gain due to particulate matter using a highprecision analytical balance (Delta Range AT261) with an accuracy of $0.01 \mathrm{mg}$. Weighing was performed after the samples had been conditioned at $30 \pm 10 \%$ relative humidity and $20 \pm 2{ }^{\circ} \mathrm{C}$ for over $24 \mathrm{~h}$. The filters were stored in a refrigerator at $4 \pm 2{ }^{\circ} \mathrm{C}$ until $2 \mathrm{~h}$ prior to the chemical analysis.

The particle concentrations measured in this study were considered to be representative of those of the local ambient particles. Hourly meteorological data (wind speed and direction) and $\mathrm{PM}_{10}$ concentrations were obtained from the MACAM network (SINCA 2011).

\section{Chemical analysis}

The collected aerosols from each filter were ultrasonically extracted for $15 \mathrm{~min}$ in $4 \mathrm{~mL}$ of deionized distilled water (18 M $\Omega$, MilliQ system, Millipore). The extracted solution was then filtered through a syringe PTFE filter with a pore size of $0.25 \mu \mathrm{m}$ (Orange Scientific, Alleud, Belgium) and was then introduced into the ion chromatograph to measure the anion and cation concentrations. All extraction and chromatographic measurement were conducted after $48-72 \mathrm{~h}$ of sampling.

Concentration analyses of anions $\left(\mathrm{Cl}^{-}, \mathrm{SO}_{4}{ }^{2-}\right.$ and $\left.\mathrm{NO}_{3}{ }^{-}\right)$and cations $\left(\mathrm{NH}_{4}{ }^{+}, \mathrm{Ca}^{2+}, \mathrm{K}^{+}\right)$were performed using a Dionne ionic chromatograph (model DX-120) with a conductivity detector. The guard column and the column used for anions were IonPack AG14 Dionex and IonPack AS14 Dionex columns, respectively. The guard column and column used for the cation analysis were IonPack CS12a Dionex and IonPack CG12a columns, respectively.

For the anion analysis, the mobile phase was a mixture of $2.7 \mathrm{mmol} \mathrm{L}^{-1}$ sodium carbonate and $0.3 \mathrm{mmol} \mathrm{L}-1$ sodium bicarbonate at a flow rate of $1.5 \mathrm{~mL} \mathrm{~min}^{-1}$. The cations were analyzed using methane sulfonic acid as the eluent at $1 \mathrm{~mL} \mathrm{~min}^{-1}$. In both cases, we used a sample volume of $25 \mu \mathrm{L}$. Species were detected using a conductivimeter detector. Ionic species were identified and quantified by interpolation of a prepared calibration curve. The results obtained from the sampling analysis were fitted using a lognormal distribution according to the size distribution.

A detection limit was used to determine the lowest concentration level that could be determined to be statistically different from a blank. The method detection limit (MDL) was $0.079,0.132$, and $0,113 \mathrm{mgL}^{-1}$ for $\mathrm{Cl}^{-}, \mathrm{SO}_{4}{ }^{2-}$, and $\mathrm{NO}_{3}{ }^{-}$, respectively and $0.056,0.034$, and $0.122 \mathrm{mgL}^{-1}$ for $\mathrm{NH}_{4}{ }^{+}$, $\mathrm{Ca}^{2+}$, and $\mathrm{K}^{+}$, respectively.

$\mathrm{NH}_{4} \mathrm{NO}_{3}$ formed in fine particles has a high volatility and therefore dissociates into gas-phase nitric acid and ammonia at ambient temperatures higher than $25^{\circ} \mathrm{C}$. Some studies suggest that some volatilization losses may occur during storage and especially for $\mathrm{NO}_{3}{ }^{-}$and $\mathrm{SO}_{4}{ }^{2-}$. This may introduce an artifact bias in measurement, which also depends on the sampling device used, particle size fraction, the composition of aerosol, the chemical form of reactive species, duration of the sample storage, and the analytical technique used (Leiva et al. 2012). In this work, soon after collection, the samples were removed and stored in sealed containers under refrigeration. Kept in coolers for transport between the sampling site and laboratory, and followed proper preservation procedures to minimize this bias.

Various equivalent concentration ratios were calculated for the water-soluble inorganic species, including the ion balance (expressed as the ratio of total cations equivalents to total anion equivalents) and the ratios $\mathrm{SO}_{4}{ }^{2-} / \mathrm{NO}_{3}{ }^{-}$, $\mathrm{NH}_{4}{ }^{+} / \mathrm{SO}_{4}{ }^{2-}, \mathrm{NH}_{4}{ }^{+} / \mathrm{NO}_{3}{ }^{-}$and $\mathrm{NH}_{4}{ }^{+} /\left(\mathrm{NO}_{3}{ }^{-}+\mathrm{SO}_{4}{ }^{2-}\right)$ at different mode of particle size.

\section{Results and discussion}

Ambient conditions during sampling and $\mathrm{PM}_{10}$ and $\mathrm{PM}_{2.5}$ concentration

The sampling periods, May 15-19 (M1), May 19-22 (M2), May 29-June 2 (M3), June 2-5 (M4), June 12-16 (M5) and June 16-19 (M6), revealed 8 polluted days (with a 24-h 
average $\mathrm{PM}_{10}$ concentration greater than $150 \mu \mathrm{g} \mathrm{m}^{-3}$ ) and 15 normal days (with a $24 \mathrm{~h}$ average $\mathrm{PM}_{10}$ concentration lower than $150 \mu \mathrm{g} \mathrm{m}^{-3}$ ), according to data obtained from the Pudahuel station of the MACAM network (Fig. 2). The sampling periods with good air quality were M5 + M6. In contrast, the M1 + M2 and M3 + M4 sampling periods exhibited poor air quality according to the national airquality standards for $\mathrm{PM}_{10}\left(150 \mu \mathrm{g} \mathrm{m}^{-3}\right)$ (Morales and Leiva 2006; SINCA 2011).

Pudahuel exhibits very high atmospheric stability during the winter. The mean RH and temperature values ranged from $57 \pm 16 \%$ (at 15:00 h) to $90 \pm 9 \%$ (at 06:00 h) and $7.27 \pm 3.07{ }^{\circ} \mathrm{C}$ (at 08:00 h) to $15.9 \pm 2.7^{\circ} \mathrm{C}$ (at 15:00 h) during the sampling periods (Fig. $3 \mathrm{a}, \mathrm{b}$ ). The highest RH was recorded at night and in early morning hours (04:00-08:00 h), while the minimum values were recorded in the central hours of the day (12:00-14:00 h). High wind speeds, Fig. 3c, were recorded between 14:00 and 21:00 h, with values ranging from $1.4 \pm 1.1$ to $2.3 \pm 1.4 \mathrm{~m} \mathrm{~s}^{-1}$. Lower speeds were recorded between 21:00 and 6:00 h, with values ranging from $0.7 \pm 0.8$ to $1.0 \pm 0.7 \mathrm{~m} \mathrm{~s}^{-1}$. Regarding the wind direction, during the afternoon the wind comes from the southwest $\left(200-240^{\circ}\right)$, whereas at night the wind comes from the southeast $\left(150-200^{\circ}\right)$; this pattern is consistent with the mountain-valley breeze pattern observed in Santiago (Morales and Leiva 2006). There were no dramatic differences in $\mathrm{RH}$ and $\mathrm{T}$ during the sampling periods. At high level of RH and lower temperature, the formation of the stable secondary aerosols was thermodynamically favored (Krupa 2003; Morata et al. 2008).
The average of $\mathrm{PM}_{10}$ and $\mathrm{PM}_{2.5}$ in the sampling period varied from 86 to 127 and 42 to $72 \mu \mathrm{g} \mathrm{m}^{-3}$, respectively (Fig. 3d, e). Among the three periods, M1 + M2 had the highest average of $\mathrm{PM}_{10}$ concentration $\left(127 \pm 98 \mu \mathrm{g} \mathrm{m}^{-3}\right)$ and M5 + M6 had the minimum $\left(86 \pm 59 \mu \mathrm{g} \mathrm{m}^{-3}\right)$. In the case of $\mathrm{PM}_{2.5}, \mathrm{M} 1+\mathrm{M} 2$ sampling period had the highest concentration $\left(72 \pm 50 \mu \mathrm{g} \mathrm{m}^{-3}\right)$ and $\mathrm{M} 5+\mathrm{M} 6$ had the minimum $\left(42 \pm 29 \mu \mathrm{g} \mathrm{m}^{-3}\right)$. This high concentration could be attributed to local man-made sources (combustion sources) of particulate matter and the secondary sources of particulate matter. A high correlation $\left(r^{2}=0.80\right)$ between $\mathrm{PM}_{10}$ and $\mathrm{PM}_{2.5}$ samples in Pudahuel area reveals that the temporal variations in fine particles have a significant influence on the observed variability in $\mathrm{PM}_{10}$ (Toro 2010).

The recorded $\mathrm{PM}_{2.5} / \mathrm{PM}_{10}$ ratios varied significantly between the various air-monitoring stations (Fig. 3f), ranging from 0.35 to $0.66,0.48$ to 0.85 and 0.30 to 0.63 for the M1 + M2, M3 + M4 and M5 + M6 sampling periods, respectively. In other words, $\mathrm{PM}_{2.5}$ concentrations are almost always larger than that of the coarse particle $\left(\mathrm{PM}_{2.5-10}\right)$, with an average $\mathrm{PM}_{2.5}$ being two times larger than the average coarse particle concentration.

The highest ratios were observed at night (04:0008:00 h) due to the lower temperature and higher relative humidity observed under these circumstances, a favorable meteorological condition for the formation of fine particles, see Fig. 4a, b.

The arithmetic averages of $\mathrm{PM}_{2.5} / \mathrm{PM}_{10}$ were observed to increase from $\mathrm{M} 3+\mathrm{M} 4(0.66 \pm 0.10)$ to $\mathrm{M} 1+\mathrm{M} 2$ $(0.53 \pm 0.11)$ to $\mathrm{M} 5+\mathrm{M} 6(0.48 \pm 0.09)$ and the average
Fig. $2 \mathrm{PM}_{10} 1-$ and $24-\mathrm{h}$ average concentration in sampling period. The gray area corresponds to MOUDI sampling periods

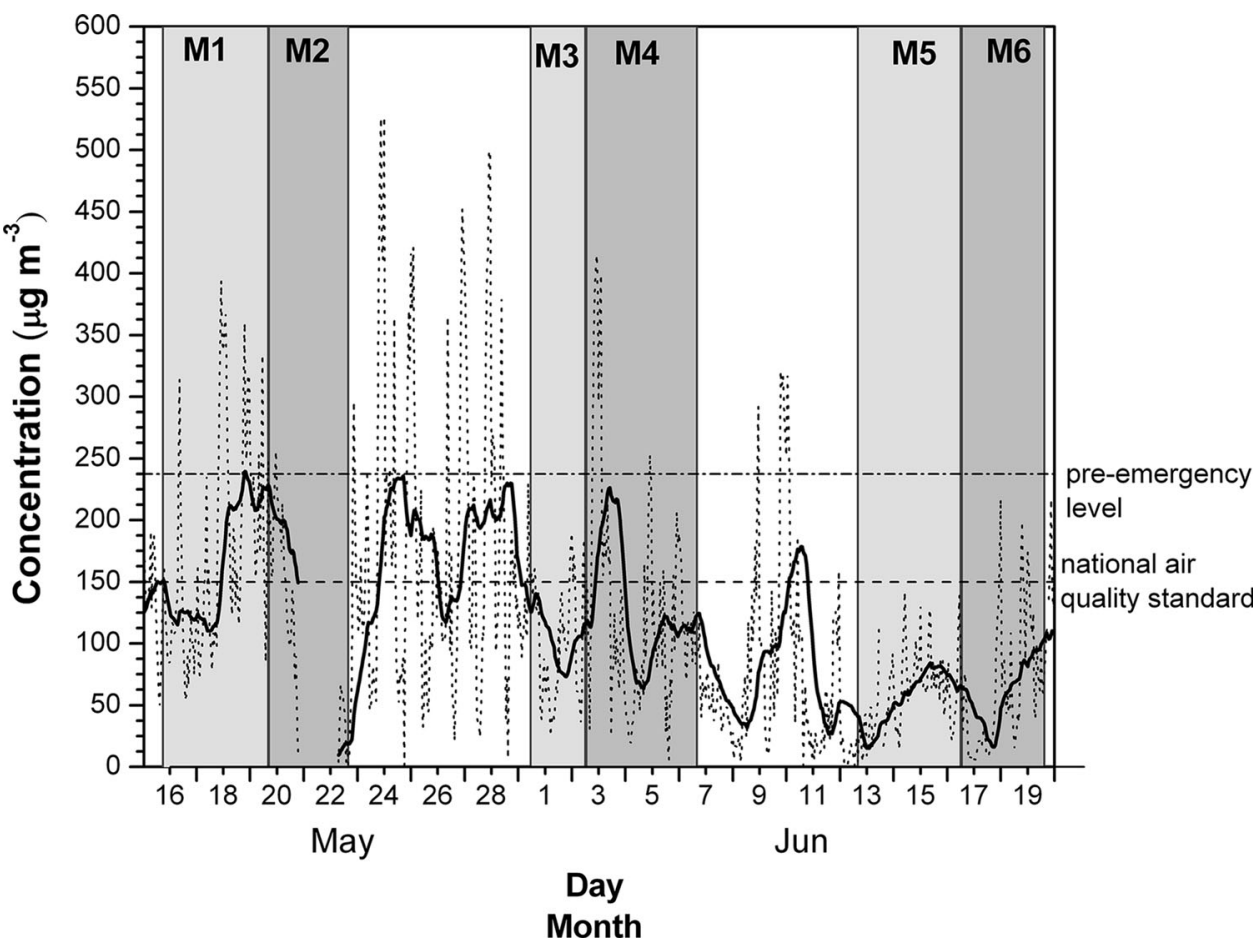



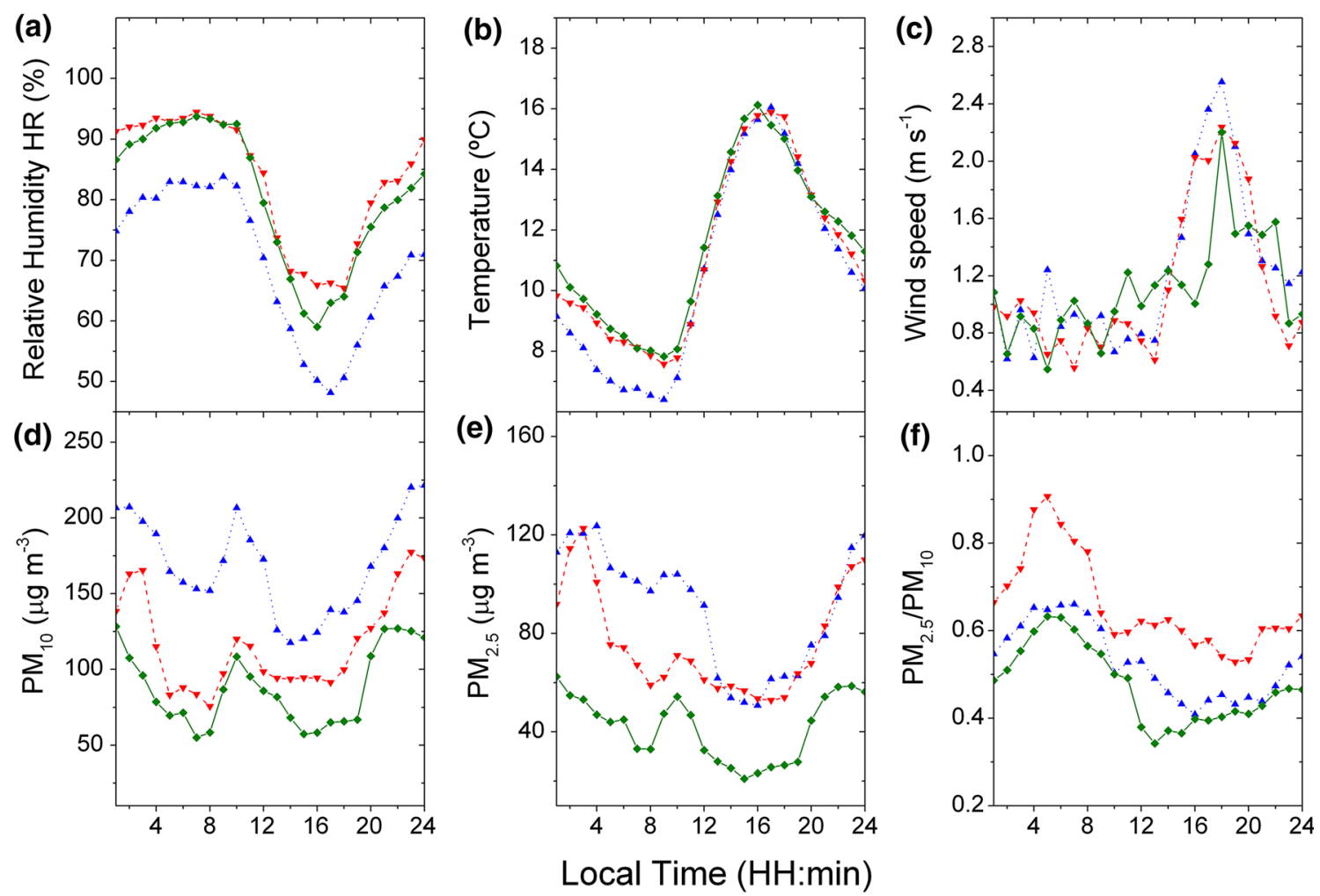

Fig. 3 Meteorological conditions (a,b and c), $\mathrm{PM}_{10}$ (d), $\mathrm{PM}_{2.5}$ (e), $\mathrm{PM}_{2.5} / \mathrm{PM}_{10}$ (f) versus local time

of the three sampling periods is 0.55 , see Fig. 4c. These results compare well to those of other urban cities like Azusa (0.51), Anaheim (0.67) (Chow et al. 1994), Montreal (0.52), and Toronto (0.60) (Brook et al. 1997).

\section{Ambient particle-size distribution mass concentrations}

The mass-size distribution of each sample is shown in Table 2 and Fig. 5a-c. The results obtained from the six sets of samples periods (M1 to M6) show the major peaks in the fine particle size mode $(0.32-1.8 \mu \mathrm{m})$, with smaller

Fig. $4 \quad \mathrm{PM}_{2.5} / \mathrm{PM}_{10}$ ratios distribution by sampling period (a) and relationship between relative humidity (b) and temperature (c) versus $\mathrm{PM}_{2.5}$ / $\mathrm{PM}_{10}$ ratios

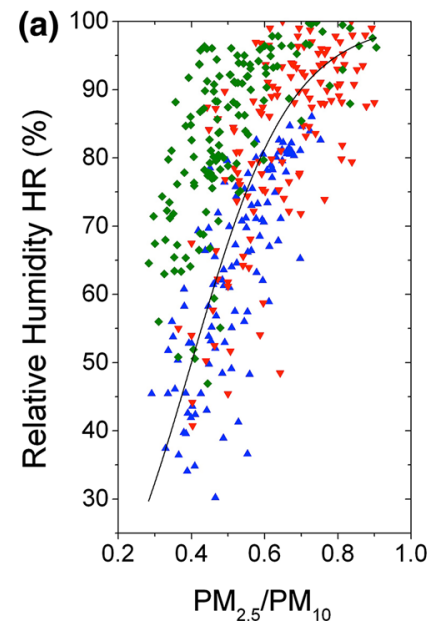

peaks occurring in the coarse $(1.8-18 \mu \mathrm{m})$ and ultrafine particle modes $(0.10-0.01 \mu \mathrm{m})$ corresponding to the ultrafine, droplet and condensation modes, with the droplet being the dominant mode. The highest and lowest particlemass concentrations were observed in the period M1 + M2 and M5 + M6, respectively.

Ion particle-size distribution

The average mass-size distribution for each stage of the MOUDI process conducted to determine the anion and
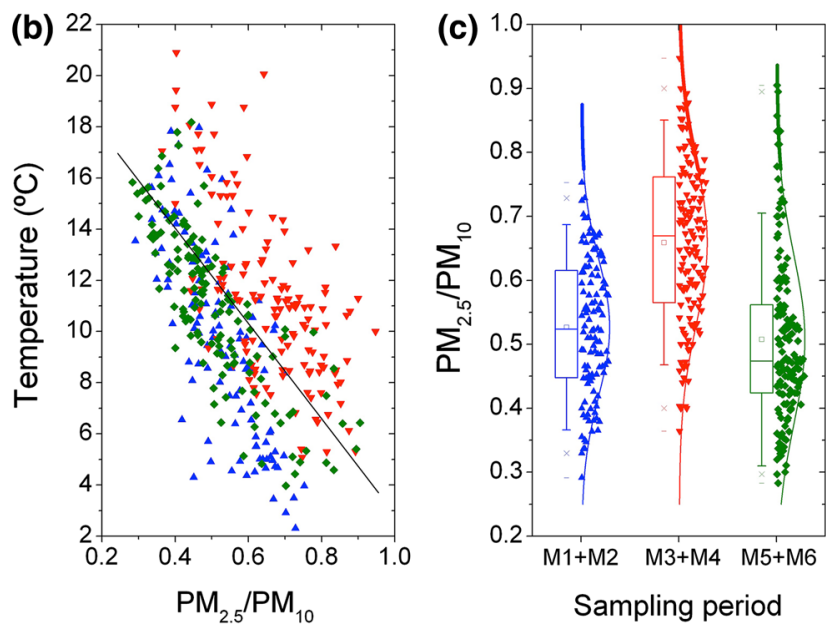
cation concentrations corresponding to each sampling periods is shown in Table 3. Water-soluble ions accounted for 11,26 , and $7 \%$ of the samples during the M1 + M2, M3 + M4, and M5 + M6 periods, respectively. Overall, nitrate, sulfate, and ammonia were the dominant ions throughout all of the sampling periods. Accumulation and coarse modes were observed, as is typical for urban aerosols. Each mode has different formation pathways. Accumulation-mode particles are likely formed by the condensation of secondary aerosol components from the gas phase, whereas mechanical processes, such as the resuspension of dust or soil, primarily form coarse-mode particles.

Anions: the particle-size distributions of chloride, sulfate, and nitrate ions

Figure 5d-f shows the size-resolved chemical composition of the particulate matter for the anions.

As shown in Fig. 5d, the size distributions of chloride are bi-modal, with the major and secondary peaks occurring at $1.8-18 \mu \mathrm{m}$ (coarse) and $0.32-1 \mu \mathrm{m}$ (fine), respectively. The chloride in the secondary peak may be in the form of ammonium chloride, which is in the fine mode and derived from the reaction of ammonia and hydrochloric acid vapor, which is emitted from combustion sources, including incinerators and power plants. Under normal atmospheric conditions, ammonium nitrate and ammonium chloride are unstable, existing in reversible phase equilibrium with their gaseous precursors such as nitric acid, hydrochloric acid, and ammonia (Krupa 2003). This equilibrium is largely controlled by both parameters: the temperature and the relative humidity. The ammonium nitrate and ammonium chloride dissociation occur at high temperatures and low relative humidity. On the other hand, these molecules are relatively stable under conditions of high relative humidity and low temperature. Chloride in the coarse mode is derived mainly from the primary emissions of sea salt, with the relatively large particle sizes reflecting the proximity of the measurement site to the ocean.

As shown in Fig. 5e, the mass-size distributions of sulfate are tri-modal, with peaks appearing at $1.8-18 \mu \mathrm{m}$ (coarse), 0.32-1 $\mu \mathrm{m}$ (fine) and $0.1-0.18 \mu \mathrm{m}$ (ultrafine). The ultrafine-mode sulfate observed in the Pudahuel area was likely to have been formed through the heterogeneous nucleation of ammonium sulfate particles (Xiu et al. 2004; Zhang et al. 2010). This explanation is consistent with the meteorological conditions in the sampling area, as can be seen in the Fig. 4a, b. Specifically, lower temperatures and higher humidity lead to a shift in the equilibrium between the gaseous and particulate phases towards the particulate phase and consequently generate greater particle mass. When the fine mode is the dominant mode, sulfate could be formed by aqueous phase reactions in droplets. The coarse-

Table 2 Mass-size distributions of particulate matter in each sample period. Percentages are shown in parentheses

\begin{tabular}{|c|c|c|c|c|c|c|}
\hline \multirow[t]{2}{*}{ Cut-point $(\mu \mathrm{m})$} & \multicolumn{6}{|c|}{ Sampling period $\left(\mu \mathrm{g} \mathrm{m}^{-3}\right)(\%)$} \\
\hline & $\begin{array}{l}\text { M1 } \\
\text { M1 + M2 }\end{array}$ & M2 & $\begin{array}{l}\text { M3 } \\
\text { M3 + M4 }\end{array}$ & M4 & $\begin{array}{l}\text { M5 } \\
\text { M5 + M6 }\end{array}$ & M6 \\
\hline 18 & $\begin{array}{l}5.06(4.6) \\
4.795(5.1)\end{array}$ & $4.53(5.8)$ & $\begin{array}{l}3.03(2.9) \\
3.85(4.6)\end{array}$ & $4.67(7.1)$ & $\begin{array}{l}2.68(7.3) \\
5.03(8.4)\end{array}$ & $7.37(8.8)$ \\
\hline 3.2 & $\begin{array}{l}29.7(27.2) \\
20.515(22.0)\end{array}$ & $11.33(14.6)$ & $\begin{array}{l}12.5(12.1) \\
10.56(12.5)\end{array}$ & $8.62(13.1)$ & $\begin{array}{l}9.45(25.9) \\
15.3(25.4)\end{array}$ & $21.2(25.2)$ \\
\hline 1.8 & $\begin{array}{l}5.5(5.0) \\
5.015(5.4)\end{array}$ & $4.53(5.8)$ & $\begin{array}{l}7.37(7.1) \\
5.765(6.8)\end{array}$ & $4.16(6.3)$ & $\begin{array}{l}2.08(5.7) \\
3.34(5.6)\end{array}$ & $4.60(5.5)$ \\
\hline 1.0 & $\begin{array}{l}6.38(5.9) \\
6.415(6.9)\end{array}$ & $6.45(8.3)$ & $\begin{array}{l}24.8(24.0) \\
21.51(25.5)\end{array}$ & $18.7(27.8)$ & $\begin{array}{l}2.16(5.9) \\
4.24(7.1)\end{array}$ & $6.32(7.6)$ \\
\hline 0.56 & $\begin{array}{l}18.4(16.9) \\
20.365(21.8)\end{array}$ & 22.3 (28.7) & $\begin{array}{l}29.3(28.5) \\
21.0(24.9)\end{array}$ & $12.7(19.3)$ & $\begin{array}{l}4.54(12.4) \\
11.9(19.9)\end{array}$ & $19.3(23.2)$ \\
\hline 0.32 & $\begin{array}{l}19.9(18.3) \\
17.6(18.8)\end{array}$ & $15.2(19.5)$ & $\begin{array}{l}14.9(14.5) \\
11.46(13.6)\end{array}$ & $8.02(12.2)$ & $\begin{array}{l}7.07(19.4) \\
10.6(17.6)\end{array}$ & $14.1(16.9)$ \\
\hline 0.18 & $\begin{array}{l}6.89(6.3) \\
5.45(5.8)\end{array}$ & $4.01(5.2)$ & $\begin{array}{l}3.42(3.3) \\
2.775(3.3)\end{array}$ & $2.13(3.2)$ & $\begin{array}{l}1.94(5.3) \\
2.025(3.4)\end{array}$ & $2.11(2.5)$ \\
\hline 0.10 & $\begin{array}{l}13.5(12.4) \\
9.80(10.5)\end{array}$ & $6.10(7.8)$ & $\begin{array}{l}5.28(5.1) \\
4.77(5.7)\end{array}$ & $4.26(6.5)$ & $\begin{array}{l}4.47(12.3) \\
4.78(8.0)\end{array}$ & $5.08(6.1)$ \\
\hline$<0.01$ & $\begin{array}{l}3.66(3.4) \\
3.49(3.7)\end{array}$ & $3.31(4.3)$ & $\begin{array}{l}2.48(2.4) \\
2.71(3.2)\end{array}$ & $2.94(4.5)$ & $\begin{array}{l}2.08(5.7) \\
2.81(4.7)\end{array}$ & $3.54(4.2)$ \\
\hline
\end{tabular}


Fig. 5 MOUDI total, anion and cations mass-size distributions of particulate matter during each sample periods

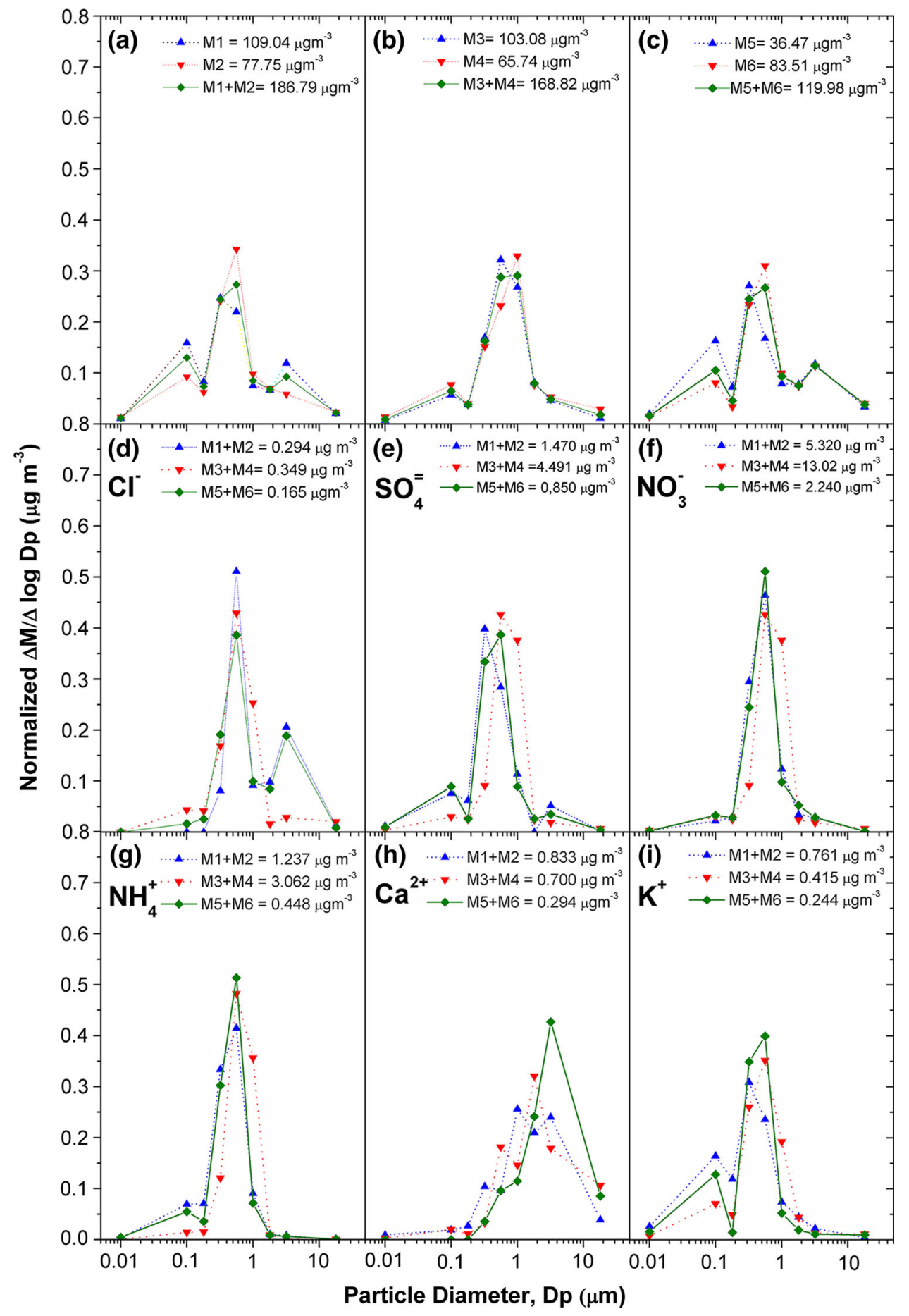

mode sulfate may have been formed by reactions of gasphase $\mathrm{SO}_{2}$ or $\mathrm{H}_{2} \mathrm{SO}_{4}$ in pre-existing sea-salt or soil particles. The reaction of $\mathrm{H}_{2} \mathrm{SO}_{4}$ with crustal aerosols is of minor importance.

The mass-size distributions of nitrate are uni-modal, with higher amounts in the fine $(0.32-1 \mu \mathrm{m})$ mode over the three sampling periods studied, as shown in Fig. 5f. The uni-modal distribution may be explained by the formation of nitrate by the homogeneous gas-phase transformation of $\mathrm{NO}_{\mathrm{x}}$ into $\mathrm{HNO}_{3}$, which later reacts with pre-existing fine particles. Moreover, $\mathrm{HNO}_{3}$ can react with $\mathrm{NH}_{3}$ in the atmosphere to form $\mathrm{NH}_{4} \mathrm{NO}_{3}$ in the fine mode, which is consistent with the modal distribution of ammonium ions. In fact, the chemistry favors the production of this salt at high humidity and low temperature (Morales and Leiva 2006). 
Table 3 Ion mass-size distributions of particulate matter in each sample period

\begin{tabular}{|c|c|c|c|c|c|c|c|c|c|c|c|c|c|c|}
\hline \multirow{3}{*}{$\begin{array}{l}\text { Cut-point } \\
(\mu \mathrm{m})\end{array}$} & \multicolumn{14}{|c|}{ Cations $\left(\mu \mathrm{g} \mathrm{m}^{-3}\right)$} \\
\hline & \multicolumn{6}{|c|}{ Ammonia } & \multicolumn{5}{|c|}{ Calcium } & \multicolumn{3}{|l|}{ Potassium } \\
\hline & \multicolumn{2}{|c|}{$\mathrm{M} 1+\mathrm{M} 2$} & \multicolumn{2}{|c|}{$\mathrm{M} 3+\mathrm{M} 4$} & \multicolumn{2}{|c|}{ M5 + M6 } & \multicolumn{2}{|c|}{$\mathrm{M} 1+\mathrm{M} 2$} & \multicolumn{2}{|c|}{$\mathrm{M} 3+\mathrm{M} 4$} & M5 + M6 & $\mathrm{M} 1+\mathrm{M} 2$ & $\mathrm{M} 3+\mathrm{M} 4$ & M5 + M6 \\
\hline 18 & \multicolumn{2}{|c|}{$<\mathrm{DL}(0.0)$} & \multicolumn{2}{|c|}{$0.002(0.1)$} & \multicolumn{2}{|c|}{$0.002(0.4)$} & \multicolumn{2}{|c|}{$0.061(7.3)$} & \multicolumn{2}{|c|}{$0.140(20.0)$} & 0.037 (12.6) & $0.009(1.2)$ & $0.013(3.1)$ & $0.006(2.7)$ \\
\hline 3.2 & \multicolumn{2}{|c|}{$0.029(2.3)$} & \multicolumn{2}{|c|}{$0.013(0.4)$} & \multicolumn{2}{|c|}{$0.010(1.8)$} & \multicolumn{2}{|c|}{0.378} & \multicolumn{2}{|c|}{$0.238(34.0)$} & $0.186(63.3)$ & $0.045(5.9)$ & $0.015(3.6)$ & $0.007(3.1)$ \\
\hline 1.8 & \multicolumn{2}{|c|}{$0.012(1.0)$} & \multicolumn{2}{|c|}{$0.028(0.9)$} & \multicolumn{2}{|c|}{$0.005(0.9)$} & \multicolumn{2}{|c|}{$0.110(13.2)$} & 0.1 & $42(20.3)$ & 0.035 (11.9) & $0.030(3.9)$ & $0.017(4.1)$ & $0.004(1.8)$ \\
\hline 1.0 & 0.11 & $(9.1)$ & 1.05 & $(35.9)$ & 0.03 & $(7.1)$ & 0.13 & $7(16.4)$ & 0.0 & $66(9.4)$ & $0.017(5.8)$ & $0.051(6.7)$ & $0.076(18.3)$ & $0.011(4.9)$ \\
\hline 0.56 & 0.50 & $(40.9)$ & 1.46 & (47.9) & 0.27 & $5(50.4)$ & 0.05 & $1(6.1)$ & 0.08 & 81 (11.6) & $0.014(4.8)$ & $0.160(21.0)$ & 0.137 (33.0) & $0.083(37.1)$ \\
\hline 0.32 & 0.39 & $(31.8)$ & 0.35 & $(11.6)$ & 0.15 & $7(28.6)$ & 0.05 & $3(6.4)$ & 0.0 & $14(2.0)$ & $0.005(1.7)$ & $0.202(26.5)$ & 0.098 (23.6) & $0.07(31.3)$ \\
\hline 0.18 & 0.08 & $(7.0)$ & 0.0 & $(1.5)$ & 0.01 & (3.5) & 0.01 & $4(1.7)$ & 0.0 & $05(0.7)$ & $<\mathrm{DL}(0.0)$ & $0.080(10.5)$ & 0.019 (4.6) & $0.003(1.3)$ \\
\hline 0.10 & 0.08 & $(7.0)$ & 0.0 & $(1.4)$ & 0.03 & $(5.5)$ & 0.01 & $(1.2)$ & 0.00 & $09(1.3)$ & $<\mathrm{DL}(0.0)$ & $0.113(14.8)$ & $0.028(6.7)$ & $0.027(12.1)$ \\
\hline$<0.01$ & 0.01 & $(1.1)$ & 0.01 & $(0.3)$ & 0.01 & $(1.8)$ & 0.01 & (2.3) & 0.00 & $05(0.7)$ & $<\mathrm{DL}(0.0)$ & $0.071(9.3)$ & $0.012(2.9)$ & $0.013(5.8)$ \\
\hline Cut-point & $\mu \mathrm{m})$ & Anions & $\left(\mu \mathrm{g}_{\mathrm{l}}\right.$ & & & & & & & & & & & \\
\hline & & Chlorin & & & & & & Sulfate & & & & Nitrate & & \\
\hline 18 & & 0.008 & & $0.019(5$ & 5.4) & 0.003 & $1.8)$ & $0.01(0$. & & $0.08(1.9)$ & $0.01(1.2)$ & $0.02(0.4)$ & $0.079(0.6)$ & $0.01(0.4)$ \\
\hline 3.2 & & 0.126( & 2.9) & $0.027(7$ & 7.7) & 0.067 & 40.6) & $0.20(13$ & $3.6)$ & $0.23(5.1)$ & $0.08(9.4)$ & $0.44(8.3)$ & $0.322(2.5)$ & $0.18(8.0)$ \\
\hline 1.8 & & $0.02(6$ & & $0.005(1$ & 1.4) & $0.01(6$ & & $<\mathrm{DL}(0$ & & $0.10(2.2)$ & $0.02(2.4)$ & $0.17(3.2)$ & $0.242(1.9)$ & $0.11(4.9)$ \\
\hline 1.0 & & 0.019 & 6.5) & $0.082(2$ & 23.5) & 0.012 & 7.3) & $0.15(10$ & $.2)$ & $1.61(35.9)$ & $0.07(8.2)$ & $0.63(11.8)$ & $4.23(32.5)$ & $0.21(9.4)$ \\
\hline 0.56 & & 0.105 & 35.7) & 0.137 & 39.3) & 0.046 & 27.9) & $0.37(25$ & 5.2) & $1.80(40.1)$ & $0.3(35.3)$ & $2.33(43.8)$ & $6.319(48.5)$ & $1.08(48.2)$ \\
\hline 0.32 & & 0.016( & 5) & $0.052(1$ & 14.9) & 0.022( & 13.3) & $0.5(34$. & & $0.37(8.3)$ & $0.25(29.4)$ & $1.43(26.9)$ & $1.325(10.2)$ & $0.5(22.3)$ \\
\hline 0.18 & & $<\mathrm{DL}$ & & $0.013(3$ & 3.7) & 0.003 & 1.8) & $0.08(5$. & & $0.10(2.3)$ & $0.02(2.4)$ & $0.14(2.6)$ & $0.236(1.8)$ & $0.06(2.7)$ \\
\hline 0.10 & & $<\mathrm{DL}$ & & $0.014(4$ & 4.0) & 0.002( & 1.2) & $0.1(6.8$ & & $0.13(2.9)$ & $0.07(8.2)$ & $0.11(2.1)$ & 0.245 (1.9) & $0.07(3.1)$ \\
\hline$<0.01$ & & $<\mathrm{DL}$ & & $<$ DL $(0$ & & $<\mathrm{DL}(0$ & & $0.06(4$. & & $0.06(1.3)$ & $0.03(3.5)$ & $0.05(0.9)$ & $0.021(0.2)$ & $0.02(0.9)$ \\
\hline
\end{tabular}

Percentages of the total ion concentration are shown in parentheses

Cations: the particle-size distributions of ammonium, calcium, and potassium ions

Figure $5 \mathrm{~g}-\mathrm{i}$ shows the size-resolved chemical composition of the particulate matter for the cations examined in this study.

The size distributions of ammonium show a bi-modal behavior with a peak in fine and ultrafine mode, as shown in Fig. 5g. This mode is consistent with the notion that fine-particle ammonium is derived from ammonia vapor as a result of the vapor reacting or condensing on particle surfaces and accumulating in the droplet mode. The reaction of ammonia with sulfuric acid or ammonium bisulfate is favored over its reaction with nitric acid. However, significant amounts of ammonium nitrate are formed in the Pudahuel area, where sulfate levels are low and ammonia and nitrogen oxide levels are high. However, ammonium must first combine with sulfate prior to nitrate and chloride because ammonium sulfate is more stable than the other possible products (Krupa 2003). The mass-size distribution of fine mode ammonium is consistent with that of sulfate, indicating that reactions involving sulfuric acid and ammonia in the particulate phase and sulfur dioxide accumulate mass in the fine mode (Behera and Sharma 2010; Krupa 2003).

The size distributions of calcium are bi-modal. The major and secondary peaks of calcium fall in the size ranges of $1.8-18 \mu \mathrm{m}$ (coarse) and $0.32-1 \mu \mathrm{m}$ (fine), respectively, as shown in Fig. 4h. Furthermore, a significant increase of the calcium content in the coarse-particle mode is due primarily to crustal materials such as calcite $\left(\mathrm{CaCO}_{3}\right)$ and dolomite $\left(\mathrm{CaMg}\left(\mathrm{CO}_{3}\right)_{2}\right)$. It is well known how limestone soils often contribute substantially to the mineral dust aerosol. On the other hand, carbonate-containing minerals in the atmosphere can react with nitric or sulfuric acids to form $\mathrm{Ca}\left(\mathrm{NO}_{3}\right)_{2}$ or $\mathrm{CaSO}_{4}$ (Meszaros et al. 1997; Salve et al. 2007).

Potassium exhibits a bi-modal distribution. The major and secondary peaks are in the size ranges of fine and ultrafine particles, as shown in Fig. 5i. This size distribution suggests that most of the potassium found in the fine 
and ultrafine mode is due to emissions from biomass burning and from the open burning of waste materials (Morales and Leiva 2006). In the city of Santiago, the burning of biomass from rural zones represents a second source of $\mathrm{PM}_{10}$ and could be an important source of fine particles (Hays et al. 2002).

Ionic balance and ratios of cationic and anionic species and relationship between $\mathrm{NH}_{4}{ }^{+}, \mathrm{NO}_{3}{ }^{-}$and $\mathrm{SO}_{4}{ }^{2-}$ at different mode of particle size.

Table 4 showed the best linear correlation and correlation coefficient for the coarse, fine, and ultrafine modes of anions versus cations $\left(\mathrm{NO}_{3}{ }^{-}+\mathrm{SO}_{4}^{2-}+\mathrm{Cl}^{-}\right.$vs. $\mathrm{NH}_{4}{ }^{+}+$ $\left.\mathrm{Ca}^{2+}+\mathrm{K}^{+}\right)$, Nitrate versus Sulfate $\left(\mathrm{NO}_{3}^{-}\right.$vs. $\left.\mathrm{SO}_{4}^{2-}\right)$, ammonium versus sulfate $\left(\mathrm{NH}_{4}^{+}\right.$vs. $\left.\mathrm{SO}_{4}^{2-}\right)$, and ammonium versus the sum of nitrate and sulfate $\left(\mathrm{NH}_{4}{ }^{+}\right.$vs. $\mathrm{NO}_{3}{ }^{-}+\mathrm{SO}_{4}^{2-}$ ), in the equivalent concentrations (neq $\mathrm{m}^{-3}$ ) for the sampling periods.

Ion balance expressed by the sum of the equivalent concentration of anions-to-cations (C/A) showed a good linear correlation $\left(r^{2}>0.60\right)$ for three modes (coarse, fine and ultrafine). The slopes values in coarse and ultrafine modes were ranged from $0.72 \pm 0.22$ to $0.64 \pm 0.03$ (see Table 4). The observed anion deficit is ascribed to the presence of $\mathrm{HCO}_{3}{ }^{-}$and water-soluble organic anions (such as organic acidic ions) have not been considered. On the other hand, the slope value in fine mode was $1.51 \pm 0.07$, where the cation deficit can be attributed to the acidity of fine mode.

Nitrate-Sulfate ratio $\left(\mathrm{NO}_{3}{ }^{-} / \mathrm{SO}_{4}{ }^{2-}\right)$ in equivalent concentration $\left(\mathrm{meq} \mathrm{m}^{-3}\right.$ ) indicates the contribution of nitrate and sulfate to aerosol and also indicates the possible sources of aerosol. Lower $\mathrm{NO}_{3}{ }^{-} / \mathrm{SO}_{4}{ }^{2-}$ ratio indicates the more static sources and higher $\mathrm{NO}_{3}{ }^{-}$/ $\mathrm{SO}_{4}{ }^{2-}$ ratio indicates more mobile sources (Arimoto et al. 1996). In this sense the $\mathrm{NO}_{3}{ }^{-} / \mathrm{SO}_{4}{ }^{2-}$ showed a good linear correlation $\left(r^{2}>0.87\right)$ for three modes (coarse, fine and ultrafine). The slopes values were $1.3 \pm 0.20,2.5 \pm 0.1$, and $1.4 \pm 0.2$ for the coarse, fine, and ultrafine modes, respectively. These results indicate that the samples have a deficit of sulfate with respect to nitrate in the three modes (see Table 4).

The equivalent concentration of $\mathrm{NH}_{4}{ }^{+}$versus $\mathrm{SO}_{4}{ }^{2-}$ and $\mathrm{NH}_{4}{ }^{+}$versus $\left(\mathrm{SO}_{4}{ }^{2-}+\mathrm{NO}_{3}{ }^{-}\right)$reveals a good linear correlation $\left(r^{2}>0.72\right.$ and $>0.66$, respectively). In the case of
$\mathrm{NH}_{4}{ }^{+}$versus $\mathrm{SO}_{4}{ }^{2-}$ the slopes are $<1$ in coarse mode and $>1$ in the fine and ultrafine mode, which reveals that in the case of fine and ultrafine mode $\mathrm{SO}_{4}{ }^{2-}$ and $\mathrm{NH}_{4}{ }^{+}$most likely exist as $\left(\mathrm{NH}_{4}\right)_{2} \mathrm{SO}_{4}$. The results show that the ammonium concentration in air is insufficient to balance the combined sulfate and nitrate concentrations. In the neutralization of the precursor gases $\left(\mathrm{H}_{2} \mathrm{SO}_{4}\right.$ and $\left.\mathrm{HNO}_{3}\right)$ by $\mathrm{NH}_{3}$ gas and the formation of particulate compounds, $\mathrm{H}_{2} \mathrm{SO}_{4}$ is neutralized (first to $\mathrm{NH}_{4} \mathrm{HSO}_{4}$, then to $\left.\left(\mathrm{NH}_{4}\right)_{2} \mathrm{SO}_{4}\right)$ before the neutralization of $\mathrm{HNO}_{3}$ takes place (Seinfeld and Pandis 2006).

\section{Conclusion}

This study was conducted at Pudahuel area in the city of Santiago during the 2003 winter season to characterize the abundances of water-soluble ion constituents $\left(\mathrm{K}^{+}, \mathrm{NH}_{4}{ }^{+}\right.$, $\mathrm{Ca}^{2+}, \mathrm{Cl}^{-}, \mathrm{NO}_{3}{ }^{-}$, and $\left.\mathrm{SO}_{4}{ }^{2-}\right)$ in the eight size-segregated mode particles and led to the following conclusions.

The $\mathrm{PM}_{2.5} / \mathrm{PM}_{10}$ ratio is directly related to the concentrations of water-soluble inorganic ions. The highest $\mathrm{PM}_{2.5} /$ $\mathrm{PM}_{10}$ ratio was observed at the highest concentration of water-soluble inorganic ions. This supports the idea that the secondary aerosols play a significant role in the formation of ambient submicron particulates.

The mass-size distributions show the major peaks in the fine particle size mode $(0.32-1.8 \mu \mathrm{m})$, with smaller peaks occurring in the coarse $(1.8-18 \mu \mathrm{m})$ and ultrafine particle modes $(0.10-0.01 \mu \mathrm{m})$.

Experimental data showed that $\mathrm{NO}_{3}{ }^{-}, \mathrm{SO}_{4}{ }^{2-}$, and $\mathrm{NH}_{4}{ }^{+}$were preponderant ions in the fine particle mode at all sampling periods. Fine mode of $\mathrm{NO}_{3}{ }^{-}$dominated its concentrations. The sources of $\mathrm{SO}_{4}{ }^{2-}$ and $\mathrm{NO}_{3}{ }^{-}$not only included anthropogenic activity, but also mainly associated with the secondary pollutants that were formed from $\mathrm{SO}_{2}$ and $\mathrm{NO}_{\mathrm{x}} \cdot \mathrm{NH}_{4}{ }^{+}$and $\mathrm{Ca}^{2+}$ dominated their respective mass concentrations in the fine and coarse mode respectively.

The average equivalent concentration ratio of $\mathrm{NH}_{4}{ }^{+}$to $\mathrm{SO}_{4}{ }^{2-}$ was $2.06 \pm 0.09$ (with most ratios $>1$ in the fine and ultrafine mode, indicating the neutralization of $\mathrm{H}_{2} \mathrm{SO}_{4}$ by $\mathrm{NH}_{3}$. The excess $\mathrm{NH}_{4}{ }^{+}$was likely associated with $\mathrm{NO}_{3}{ }^{-}$ and $\mathrm{Cl}^{-}$. The charge balance between cations (i.e., $\mathrm{NH}_{4}{ }^{+}$,

Table 4 Linear correlation and correlation coefficient for the coarse, fine and ultrafine modes of anions versus cations, in the equivalent concentrations $\left(\right.$ neq $\mathrm{m}^{-3}$ ) for the sampling periods

\begin{tabular}{|c|c|c|c|c|}
\hline Mode & Cations vs. anions & $\mathrm{NO}_{3}^{-}$vs. $\mathrm{SO}_{4}^{2-}$ & $\mathrm{NH}_{4}^{+}$vs. $\mathrm{SO}_{4}^{2-}$ & $\mathrm{NH}_{4}^{+}$vs. $\mathrm{NO}_{3}^{-}+\mathrm{SO}_{4}^{2-}$ \\
\hline Coarse & $y=(0.69 \pm 0.05) x r^{2}=0.97$ & $y=(1.3 \pm 0.2) \times r^{2}=0.92$ & $y=(0.27 \pm 0.05) x r^{2}=0.74$ & $y=(0.11 \pm 0.02) x r^{2}=0.88$ \\
\hline $\begin{array}{l}\text { Fine } \\
\text { ultraFine }\end{array}$ & $\begin{array}{l}y=(0.64 \pm 0.03) x r^{2}=0.97 \\
y=(0.72 \pm 0.22) x r^{2}=0.61\end{array}$ & $\begin{array}{l}y=(2.5 \pm 0.1) \times r^{2}=0.95 \\
y=(1.4 \pm 0.2) \times r^{2}=0.88\end{array}$ & $\begin{array}{l}y=(2.1 \pm 0.1) x r^{2}=0.96 \\
y=(1.2 \pm 0.3) x r^{2}=0.73\end{array}$ & $\begin{array}{l}y=(0.60 \pm 0.01) x r^{2}=0.994 \\
y=(0.57 \pm 0.16) x r^{2}=0.67\end{array}$ \\
\hline
\end{tabular}


$\mathrm{K}^{+}$and $\mathrm{Ca}^{2+}$ ) and anions (i.e., $\mathrm{Cl}^{-}, \mathrm{NO}_{3}{ }^{-}$, and $\mathrm{SO}_{4}{ }^{2-}$ ) reveals an excess of anions in coarse and ultrafine modes and an excess of cations in fine mode. A possible explanation for this cation deficit could be that the presence of $\mathrm{HCO}_{3}{ }^{-}$and water-soluble organic anions (such as organic acidic ions) was not considered.

The observed charge balance confirmed that insufficient amounts of $\mathrm{NH}_{4}{ }^{+}$are typically present to neutralize all of the acidic components $\left(\mathrm{H}_{2} \mathrm{SO}_{4}, \mathrm{HNO}_{3}\right.$ and $\left.\mathrm{HCl}\right)$ in the fine mode and that the aerosols will be considered acidic.

Acknowledgments The authors are grateful to Centro Nacional del Medio Ambiente (CENMA) for providing the MOUDI equipment. They would like to thank the anonymous referees for providing us with constructive comments and suggestions.

\section{References}

Arimoto R, Duce RA, Savoie DL, Prospero J, Talbot R, Cullen J, Tomza U, Lewis N, Ray B (1996) Relationships among aerosol constituents from Asia and the North Pacific during PEM-West A. J Geophys Res 101:2011-2023

Baek BH, Aneja VP, Tong Q (2004) Chemical coupling between ammonia, acid gases, and fine particles. Environ Pollut 129(1): 89-98

Behera SN, Sharma M (2010) Investigating the potential role of ammonia in ion chemistry of fine particulate matter formation for an urban environment. Sci Total Environ 408(17):3569-3575

Brook JR, Wiebe AH, Woodhouse SA, Audette CV, Dann TF, Callaghan S, Piechowski M, Dabek-Zlotorzynska E, Dloughy JF (1997) Temporal and spatial relationships in fine particle strong acidity, sulphate, $\mathrm{PM}_{10}$ and $\mathrm{PM}_{2.5}$ across multiple Canadian locations. Atmos Environ 31(24):4223-4236

Chen Y-Q, Zhang Y, Zhang X-S (2005) Size distribution and seasonal variation of ions in aerosol at semi-urban site in Beijing. Acta Ecologica Sinica 25(12):3231-3236

Chow JC, Watson JG, Fujita EM, Lu Z, Lawson DR (1994) Temporal and spatial variations of $\mathrm{PM}_{2.5}$ and $\mathrm{PM}_{10}$ aerosol in the southern California air quality study. Atmos Environ 28(12):2061-2080

CONAMA RM (1999). Final Report Aerosol Characterization Study in Santiago de Chile-1999. Comisión Nacional del Medio Ambiente Región Metropolitana (CONAMA RM), Santiago, pp 69

Donaldson K, Li XY, MacNee W (1998) Ultrafine (nanometer) particle mediated lung injury. J Aerosol Sci 29(5-6):553-560

Du H, Kong L, Cheng T, Chen J, Yang X, Zhang R, Han Z, Yan Z, Ma Y (2010) Insights into ammonium particle-to-Gas Conversion: non-sulfate ammonium coupling with nitrate and chloride. Aerosol Air Qual Res 10(6):589-595

Hays MD, Geron CD, Linna KJ, Smith ND, Schauer JJ (2002) Speciation of gas phase and fine particle emissions from burning of foliar fuels. Environ Sci Technol 36(11):2281-2295

Krupa SV (2003) Effects of atmospheric ammonia $\left(\mathrm{NH}_{3}\right)$ on terrestrial vegetation: a review. Environ Pollut 124(2):179-221

Leiva MA, Araya MC, Alvarado AM, Seguel RJ (2012) Uncertainty estimation of anions and cations measured by ion chromatography in fine urban ambient particles $\left(\mathrm{PM}_{2.5}\right)$. Accredit Qual Assur 17(1):53-63
Lin CC, Chen SJ, Huang KL, Lee WJ, Lin WY, Liao CJ, Chaung HC, Chiu CH (2007) Water-soluble ions in nano/ultrafine/fine/coarse particles collected near a busy road and at a rural site. Environ Pollut 145(2):562-570

Maricq MM (2007) Chemical characterization of particulate emission from diesel engines: a review. J Aerosol Sci 38(11):1079-1118

Marple VA, Rubow KL, Behm SM (1991) A micro-orifice uniform deposit impactor (MOUDI): description, calibration and use. Aerosol Sci Tech 14(4):434-446

Meszaros E, Barcza T, Gelencser A, Hlavay J, Kiss G, Krivacsy Z, Molnar A, Polyak K (1997) Size distributions of inorganic and organic species in the atmospheric aerosol in Hungary. J Aerosol Sci 28(7):1163-1175

Milford JB, Davidson CI (1987) The sizes of particulate sulphate and nitrate in the atmosphere. J Air Pollut Contr Assoc 37(2): $125-134$

Morales RGE, Leiva GMA (2006) Distribution and Critical Concentration of PM in the city of Santiago, Chile (in Spanish). In: Morales RGE (ed) Atmospheric Urban Pollution: Critical episodes of the Environmental pollution in the City of Santiago, Chile (in Spanish), 1st edn. Editorial Universitaria SA, Santiago

Morata D, Polve M, Valdes A, Belmar M, Dinator MI, Silva M, Leiva MA, Aigouy T, Morales JR (2008) Characterisation of aerosol from Santiago, Chile: an integrated PIXE-SEM-EDX study. Environ Geol 56(1):81-95

Morawska L, Ristovski Z, Jayaratne ER, Keogh DU, Ling X (2008) Ambient nano and ultrafine particles from motor vehicle emissions: characteristics, ambient processing and implications on human exposure. Atmos Environ 42(35):8113-8138

Parmar RS, Satsangi GS, Kumari M, Lakhani A, Srivastava SS, Prakash S (2001) Study of size distribution of atmospheric aerosol at Agra. Atmos Environ 35(4):693-702

Salve PR, Krupadam RJ, Wate SR (2007) A study on major inorganic ion composition of atmospheric aerosols. J Environ Biol 28(2):241-244

Seinfeld JH, Pandis SN (2006) Atmospheric Chemistry and Physics: From Air Pollution to Climate Change. John Wiley and Sons, Inc., Hoboken

SINCA (2011) Sistema de Información Nacional de Calidad del Aire (Information National System of Air Quality). Ministerio del Medio Ambiente, Gobierno de Chile, Chile. On line database. http://sinca.conama.cl

Toro R (2010) Secondary particulate matter formation in high pollution episodes in Santiago, Chile (In spanish) Ph.D. Disertation, Faculty of Science, University of Chile, Chile, Chile

Tsai JH, Chang KL, Lin JJ, Lin YH, Chiang HL (2005) Mass-size distributions of particulate sulfate, nitrate, and ammonium in a particulate matter nonattainment region in southern Taiwan. J Air Waste Manag 55(4):502-509

Verma SK, Deb MK, Suzuki Y, Tsai YI (2010) Ion chemistry and source identification of coarse and fine aerosols in an urban area of eastern central India. Atmos Res 95(1):65-76

Wichmann HE, Spix C, Tuch T, Wölke G, Peters A, Heinrich J, Kreyling G, Heyder J (2000) Daily mortality and fine and ultrafine particles in Erfurt, Germany. Part-I: Role of particle number and particle mass Health Effects Institute, Research report, number 98, Germany

Xiu GL, Zhang DN, Chen JZ, Huang XJ, Chen ZX, Guo HL, Pan JF (2004) Characterization of major water-soluble inorganic ions in size-fractionated particulate matters in Shanghai campus ambient air. Atmos Environ 38(2):227-236 
Zhang WJ, Zhuang GS, Guo JH, Xu DQ, Wang W, Baumgardner D, Wu ZY, Yang W (2010) Sources of aerosol as determined from elemental composition and size distributions in Beijing. Atmos Res 95(2-3):197-209
Zhao JP, Zhang FW, Xu Y, Chen JS (2011) Characterization of watersoluble inorganic ions in size-segregated aerosols in coastal city Xiamen. Atmos Res 99(3-4):546-562 